\title{
The Influence of Organizational Culture and Employee Engagement on Employees Performance at Telkom University, Indonesia
}

\author{
Aditya Fathur Rohman ${ }^{1}$, Dian Indiyati ${ }^{2}$, Astri Ghina ${ }^{3}$ \\ ${ }^{1,2,3}$ Faculty of Economic and Business, Telkom University, Indonesia \\ Email: aditfathurrohman@student.telkomuniversity.ac.id
}

\begin{abstract}
The performance of a college is very dependent on the performance of its employees. Therefore, Telkom University must pay attention to the factors that affect the performance of its employees, including organizational culture and employee engagement. This study aims to determine how the organizational culture at Telkom University, how Employee engagement and employee performance at Telkom University, and to test and analyze the influence of Organizational Culture and Employee Engagement on Employee Performance. The population in this study was 1247 permanent employees at Telkom University, obtained based on data from the Telkom University HR Directorate as of August 2020, the sampling technique used was Proportional Stratified Random Sampling by taking representatives from the Faculties and Directorates. Calculated using the Slovin formula, in order to obtain the number of respondents as many as 303 people. The data collection technique uses a questionnaire that has been tested for validity and reliability, while the data analysis technique uses multiple regression analysis. The results of this study indicate that the Organizational Culture at Telkom University is in the Strong category, Employee Engagement is in the High category, and the employee's performance is above the target. Furthermore, organizational culture and employee engagement have a positive and significant effect on the performance of Telkom University employees, either partially or simultaneously.
\end{abstract}

Keywords: Organizational Culture, Employee Engagement, Employee Performance, Telkom University.

\section{A. INTRODUCTION}

Organizational culture plays an important role in improving the effective performance of an organization. For organizations, culture is a benchmark for achieving organizational success while building a commitment to realizing the vision, winning the hearts of customers, winning the competition and building company strength. For individuals, the culture encourages employees to have a high sense of trust in the organization and to be more productive. Organizational goals can be achieved if you have employees who have good skills and are competent so they can excel in competition (Suharno, 2017). Organizational culture is something that is fundamental, even if the organization has a strong culture, where all members of the organization carry out its cultural values, then the organization can create its competitive advantage (Indiyati, 2014, Indiyati, 2018).

According to Siagian (2008) organizational culture can specifically be determined by the conditions of teamwork, leadership, organizational characteristics and applicable administrative processes. In its function, organizational culture is also an employee unifier, a reducer of conflict and a motivator for employees to 
carry out their duties properly, thereby affecting employee performance.

Attention to the importance of employee performance cannot be separated from the factors that can affect employee performance in the company. One of the factors that can affect employee performance is employee engagement. Management or employee engagement arises because of the alignment between the values that exist in the company and the character of the employees (Jane, 2018). Employee Engagement is manifested as energy, engagement and focused efforts to achieve company goals (Macey et al., 2009). Employee performance can be influenced by employee engagement, this is supported by (Schaufeli et al., 2006) which states that employees who are bound will continue to work with positive thoughts, so that they are faster or more likely to complete other things at work.

Employee Engagement can be defined as an emotional and intellectual commitment to the organization (Aktar, 2017), the characteristics of employee engagement as a condition that provides positive motivation for employees are described by the existence of vigor, dedication, and absorption. Vigor is an employee's attachment that is shown through their physical and mental strength while doing work (Schaufeli et al, 2006). Dedication is an employee's emotional attachment to his job. Dedication describes the morale of employees at work, proud of the work done and the company where they work (Schaufeli \& Bakker, 2006). Absorption is employee attachment which is described through the behavior of employees who pay full attention to their work. Absorption shows the condition of employees who feel happy to be carried away, and have a high concentration in doing their work. According to Aktar (2017) states that Employee Engagement can lead to individual work results such as quality of work and work experience of an employee, for the results received by the organization, such as organizational growth and productivity.

Telkom University has a mission to maximize the use of technology, science, and art for the welfare and advancement of national civilization through the development of entrepreneurial competencies. Therefore, in an effort to achieve the vision and mission, Telkom University requires a philosophy and principles of institutional management, especially those related to employee behavior patterns, organizational culture, and strategy. This cultural entropy will form the basis for building enthusiasm, patterns of thought and direction of behavior which are absolutely things that must be owned. Underlying and harmonizing the personnel behavior patterns and organizational culture, Telkom University's main values are then formulated. These values are the basis for the behavior of every employee at Telkom University, namely Harmony, Excellence, and Integrity, abbreviated as "HEI".

This research was conducted to determine how the organizational culture at Telkom University, how employee engagement and employee performance at Telkom University, and to examine and analyze the influence of Organizational Culture and Employee Engagement on Employee Performance. 


\section{B. LITERATURE REVIEW}

\section{Organizational Culture}

Organizational culture in each company is different from other companies, organizational culture can be said to be the culture that is applied to a particular work environment. In essence, what is meant by organizational culture is a culture that is a reference in a company where a group of people interacts (Judge, 2018). According to Robbins (2017) organizational culture is a general perception that is applied by members of the organization, a system that is shared. Organizational culture is concerned with how workers perceive the characteristics of organizational culture. Organizational culture is the basic philosophy of an organization that has beliefs, norms and values as a guideline for all human resources in the organization in carrying out their activities in the work environment (Robbins, 2017).

According to Luthans (2016), organizational culture is a pattern of basic assumptions made, discovered, or developed by organizations when adjusting to external problems and internal integration that has gone quite well and is considered valuable, therefore it is taught to prospective members of new organizations as a way socially correct to think and behave in relation to problems. According to Indiyati (2014), it explains that organizational culture is something that is fundamental, which contains beliefs, shared core values, something that is a core feature that is believed and implemented jointly by all members of the organization. Organizational culture reflects the general perception carried out by all members of the organization.

Based on the above understanding, it can be concluded that organizational culture is a norm, a way of behaving, the beliefs held by organizational members to create different characteristics from other organizations to be trusted and implemented together to achieve organizational goals.

Organizational culture has several functions suggested by Robbins (2017):

a. Determinants of boundaries, meaning that culture creates a difference between one organization and another.

b. Contains a sense of identity of organizational members

c. Facilitating the rising of commitment to something that is bigger than individual interests

d. Increasing the stability of the social system, culture functions as a social glue that helps unite the organization by providing standards for what members of the organization should say and do

e. Culture defines rules of behavior, vague, intangible, but every organization develop a core set of assumptions, understandings and intangible rules that govern daily behavior in the workplace.

Every organization should manage every important element that can support performance. One important element that can support employee performance is organizational culture. With the application of a strong organizational culture, it will be embedded in the minds of organizational members. Organizational culture is able to create characteristics that will become the identity of an organization. If the 
organizational culture is well managed, it can create loyalty from members of the organization (Judge, 2018).

\section{Employee Engagement}

According to (Nabil et al, 2019) Employee Engagement is also often referred to as work engagement, which is a situation where members of an organization identify themselves with their work in an engagement or engagement, someone will employ and express themselves physically, cognitively and emotionally when showing their performance. The cognitive aspects of Employee Engagement include the beliefs employees have about the organization, its leaders and working conditions. The emotional aspect includes how employees feel about the organization and its leaders. Meanwhile, the physical aspect includes the physical energy released by employees in carrying out their roles in the organization.

There is also a view of engagement, namely assuming that engagement and burnout are opposite poles of the meaning of work related wellbeing, with burnout representing the negative pole and engagement as the positive pole. Involvement includes physical and psychological presence while carrying out organizational roles (Schaufeli et al., 2006).

Based on the description above, a measuring instrument was developed to measure aspects of vigor, dedication and absorption called the Utrecht Work Engagement Scale (UWES) (Schaufeli et al., 2006). Of the several measurement tools that measure employee engagement, the UWES is the academic measurement tool most widely used by researchers worldwide. The reason researchers use this measuring instrument is because of the clarity of the theory that underlies the measuring instrument. In addition, this measuring instrument has also been proven valid and reliable and has been used in various research countries in the world and has been adapted into ten languages in 2019.

\section{Employee Performance}

Performance is the process and the results of the efforts of individual and group organizations in a certain period. The abilities and talents possessed by each employee have different results, the success of an organization depends on the individual performance of each employee. An organization needs employees who have the talent and ability to complete their work (Kurniawan, 2018). Dessler (2016), defines employee performance as the result of the employee's actual performance compared to the employee's expected performance. Expected employee performance, achievement is a standardized achievement that is formed as a reference in order to see the performance of each individual employee in accordance with the predetermined position standards.

Employee performance appraisal is one way to measure the condition of each individual employee in the organization where the employee works. Whether or not the performance achieved by a company is influenced by the level of employee performance, both individually and in groups. With the assumption that the better 
the employee's performance, the better the performance of a company (Robbins, 2018).

According to Mathis (2016), employee performance is one aspect of a company that is of great concern to company managers. Because the success of a company is very dependent on the performance of its employees. Employee performance is something that affects how much it contributes to a company. The performance reflects how well employees meet the standards of a job. Motivate employees to work, develop individual abilities, in the future, employees can provide feedback on performance in the self-development process. Kurniawan (2018) said that employee performance is a process and the result of individual and group performance that can be accounted for, both in terms of quality, quantity, and timeliness in completing work according to the abilities and talents of employees.

\section{METHOD}

This research is a descriptive-verification-causal research, which is to determine the influence of organizational culture and employee engagement on employee performance, presented in numbers, equipped with descriptive analysis and statistical analysis. Causally, this study will prove the hypothesis based on the theory used and the previous research literature. The paradigm of this research is positivism, meaning that this research examines the cause and effect of individual behavior, the positive paradigm also explains how the relationship between the interacting variables forms an event and or produces something, the positivism paradigm is carried out using quantitative methods.

The population in this study were 1247 permanent employees at Telkom University, obtained based on data from the Telkom University HR Directorate as of August 2020, the sampling technique used was Proportional Stratified Random Sampling by taking representatives from the Faculties and Directorates. Calculated using the Slovin formula, in order to obtain the number of respondents as many as 303 people. The data collection technique uses a questionnaire that has been tested for validity and reliability, the questionnaire is distributed digitally via a link, google form application, while the data analysis technique uses multiple regression analysis.

\section{RESULT AND DISCUSSION}

\section{Organizational Culture}

Organizations must be able to encourage their employees to innovate and dare to take risks that have been adjusted to the risks that may occur in the organization. Thus, if regulations are formulated on the basis of mutual agreement, employees feel more responsible for reducing risk so as to reduce company losses (Robbins \& Judge, 2017).

Organizational culture variables are measured from 7 (seven) dimensions, namely innovation and risk taking, aggressiveness, result orientation, human orientation, team orientation, attention to detail, and stability as measured by 24 
statement indicators. Based on descriptive data exposure Respondents' responses to each dimension, it can be seen in general that the respondent's assessment of the Organizational Culture variable can be seen from the presentation of the data processing results in table 1 below:

Table 1 Recapitulation of Respondents' Responses to Organizational Culture Variables

\begin{tabular}{|c|l|c|c|c|}
\hline No & \multicolumn{1}{|c|}{ Dimensions } & Score & Percentage & Category \\
\hline 1 & Innovation and Risk Taking & 4962 & $80.55 \%$ & Strong \\
\hline 2 & Aggressiveness & 5282 & $85.74 \%$ & Very Strong \\
\hline 3 & Output Orientation & 3876 & $83.89 \%$ & Strong \\
\hline 4 & People Orientation & 3794 & $82.12 \%$ & Strong \\
\hline 5 & Team Orientation & 3939 & $85.25 \%$ & Very Strong \\
\hline 6 & Attention to Detail & 5119 & $83.10 \%$ & Strong \\
\hline 7 & Stability & 3955 & $85.60 \%$ & Very Strong \\
\hline \multicolumn{2}{|c|}{ Total } & $\mathbf{3 0 9 2 7}$ & $\mathbf{8 3 . 6 7 \%}$ & Strong \\
\hline
\end{tabular}

Source: Questionnaire Data Processing (2020)

Table 1 shows that the dimension of organizational culture that has the highest score is the aggressive attitude with a score of $5282(85.74 \%)$ in the Very strong category. Furthermore, the stability dimension has a score of $3955(85.60 \%)$, team oriented has a score of $3939(85.25 \%)$, results oriented has a score of 3876 $(83.89 \%)$, attention to detail has a score of $5119(83.10 \%)$, people oriented has a score of $3794(82.12 \%)$, and the last one Innovation and risk taking has a score of 4962 $(80.55 \%)$.

The results of this study indicate that the overall implementation of organizational culture at Telkom University is strong, meaning that Telkom University always strives to have a good belief system and work system, the applied organizational culture can serve as a guide in achieving Telkom University's general goals, running programs and social interactions. Referring to the vision of Telkom University, which wants to become an Entrepreneurial University, if you look at the entrepreneurial dimension as described by (Wong, 2014), one of the dimensions of entrepreneurship is innovation and the courage to take risks, as well as the entrepreneurial dimension. The first dimension of the dimension has an organizational culture (Robbins, 2017).

At Telkom University, the assessment score from the dimensions of innovation and the courage to take risks is still the lowest compared to the assessment of respondents from other dimensions, namely 4962 (80.55\%). This condition can be used as a reference to increase the dimensions of innovation and the courage to take risks so that it is in line with Telkom University's vision, namely, to become an Entrepreneurial University in 2023. In its social relations, organizational culture plays a unifying role. In helping organizations to unite by providing appropriate standards of what employees should say and do, which in turn becomes a mechanism for the formation and mastery of meaning to shape 
employee attitudes and behavior (Indiyati, 2014).

\section{Employee Engagement}

The definition of Employee Engagement based on opinion (Schaufeli \& Bakker, 2006) states that employee engagement is a positive condition and employee fulfillment is related to work, characteristics of employee engagement with enthusiasm (vigor), dedication, and absorption. Based on the definition described by Schaufeli (2006), it can be concluded that employee engagement is a condition of an individual employee who has a work spirit that involves physically and emotionally directs his energy, so that it will give employees the best effort at work. Aligned with the organization's strategic priorities, and find it difficult to escape from work characterized by passion, dedication, and absorption.

The theory used in this study is the theory of employee engagement according to (Schaufeli \& Bakker, 2006) with a measurement scale developed by Schaufeli as well, namely the Utrecht Work Engagement Scale (UWES) which has 16 statement indicators covering 3 dimensions of Employee Engagement. The first dimension (1) enthusiasm (vigor) is characterized by high energy at work, strong mental endurance, serious work, willingness to work, and strong persistence. The second dimension (2) Dedication is characterized by significant feelings, sacrifice of energy and thoughts, a sense of meaning, enthusiasm, inspiration, pride, and challenge. The third dimension (3) Absorption is characterized by full concentration, willingness to work, seriousness, and enjoying work where time passes, and the difficulty of employees giving up their jobs.

Based on the descriptive data exposure of the respondent's responses to each dimension, in general it can be seen that the respondent's assessment of the Employee Engagement variable can be seen from the presentation of the data processing results shown in table 2 below:

Table 2 Recapitulation of Respondents' Responses to Employee Engagement

\begin{tabular}{|c|l|c|c|c|}
\hline No. & \multicolumn{1}{|c|}{ Dimensions } & Score & Percentage & Category \\
\hline 1 & Vigor & 6355 & $82.53 \%$ & High \\
\hline 2 & Dedication & 6317 & $82.03 \%$ & High \\
\hline 3 & Absorption & 6856 & $74.19 \%$ & High \\
\hline \multicolumn{2}{|c|}{ Total } & $\mathbf{1 9 5 2 8}$ & $\mathbf{7 9 . 2 5 \%}$ & High \\
\hline
\end{tabular}

Source: Questionnaire Data Processing, 2020

The data shown in table 2 shows that the dimension of Employee Engagement that has the highest score is Vigor, which has a score of $6355(82.53 \%)$ in the Strong category. Next is the Dedication dimension which has a score of $6317(82.03 \%)$, and Absorption has a score of 6856 (74.19\%). Overall, the total score obtained is 19528 (79.52\%) from a maximum score of 24640 . The score is in the interval $>68 \%-84 \%$, which is in the Strong category. A sense of enthusiasm (vigor) is an individual's energy at work, strong mental endurance, serious work, and a high sense of perseverance (Schaufeli \& Bakker, 2006). The vigor dimension in this study consists of 5 statement indicators, namely (1) enthusiasm, (2) not easily tired, (3) not easily 
giving up, (4) strong mentality, and (5) persistence.

Dedication can be characterized as individuals who have a sense of sacrifice of energy and thoughts, a sense of meaning, enthusiasm, inspiration, pride, and challenge. An employee who has a strong sense of dedication strongly identifies with the work they experience as meaningful, inspiring, and challenging. In addition, employees usually feel enthusiastic and proud of their work (Schaufeli \& Bakker, 2006). Employees who have a weak sense of dedication usually do not identify with their job, because employees do not feel the job has meaning, does not inspire or challenge.

Absorption can be characterized as an individual who is in a job or activity who finds it difficult to get away from his job so that time flies quickly and the individual forgets everything around him (Schaufeli \& Bakker, 2006). Employees who score high in absorption usually feel that they are late in their job and have difficulty giving up their jobs. On the other hand, employees who score low in absorption do not feel absorbed in their work, they do not have difficulty letting go of their jobs.

\section{Employee Performance}

Performance is a process of personality and the results of a group within a certain period of time, the basic performance of employees becomes individually for each employee who has different work results according to their abilities and talents (Kurniawan, 2018). Organizational success depends on employee performance, organizations need high achieving and high performing employees. At the same time, employees also need feedback or self-assessment from the organization as a guide for action or performance in the next period (Kurniawan, 2018). Dessler (2016) states that employee performance is the actual achievement of employees compared to the expected performance of an organization. The work performance desired by the organization is an achievement that has been prepared as a standard reference. Based on the descriptive data exposure of the respondent's responses to each dimension, in general it can be seen that the respondent's assessment of the Employee Engagement variable can be seen from the presentation of the data processing results shown in table 3 below:

Table 3 Recapitulation of Respondent's Responses to Employee Performance Variable

\begin{tabular}{|c|l|c|c|c|}
\hline No. & \multicolumn{1}{|c|}{ Dimensions } & Score & Percentage & Category \\
\hline 1 & Quality & 5103 & $82.84 \%$ & Above Target \\
\hline 2 & Productivity & 2348 & $76.23 \%$ & Above Target \\
\hline 3 & Job Knowledge & 3839 & $83.09 \%$ & Above Target \\
\hline 4 & Trust & 2583 & $83.86 \%$ & Above Target \\
\hline 5 & Availability & 4653 & $75.53 \%$ & Above Target \\
\hline \multicolumn{2}{|r|}{ Total } & $\mathbf{1 8 5 2 6}$ & $\mathbf{8 0 . 1 9} \%$ & Above Target \\
\hline
\end{tabular}

Source: Questionnaire Data Processing, 2020 
The data displayed in table 3 shows that the employee performance dimension with the highest score is Trust with a score of $2583(83.86 \%)$ in the High category. Next is the Work Knowledge dimension with a score of $3839(83.09 \%)$, Quality has a score of 5103 (82.84\%), Productivity has a score of 2348 (76.23\%) and Availability has a score of $4653(75.53 \%)$. Overall, the total score obtained is 18526 $(80.19 \%)$ from a maximum score of 23100 . The score is in the interval $>68 \%-84 \%$ which is included in the High category.

These results indicate that the overall employee performance felt by employees at Telkom University is high, meaning that Telkom University always tries to encourage and maintain employee performance, so that Telkom University targets can be achieved. Performance appraisal has several benefits for employees, appraisers and the company. Benefits for employees as described in Fuadi's (2019) research include (1) Increasing employee motivation, (2) Increasing job satisfaction, (3) Clarity of expected work results standards, (4) Opportunity to communicate with leaders, and (5) Self assessment (Fuadi, 2019).

\section{The Influence of Organizational Culture and Employee Engagement on Employee Performance}

Determination coefficient shows how much the independent variable is able to explain the effect on the dependent variable, as measured by the correlation value. The results of data processing at SPSS for this study are shown in the following table:

Table 4 Correlation Coefficient

\begin{tabular}{|l|r|r|r|r|}
\hline Model & R & R Square & \multicolumn{1}{c|}{$\begin{array}{c}\text { Adjusted } R \\
\text { Square }\end{array}$} & $\begin{array}{c}\text { Std. Error of the } \\
\text { Estimate }\end{array}$ \\
\hline 1 & 0,719 & 0,517 & 0,514 & 0,24815 \\
\hline
\end{tabular}

a. Predictors: (Constant), Employee Engagement, Organizational Culture

b. Dependent Variable: Employee Performance

Source: Research Data Analyze, 2020

Based on table 4.4, from the results of data processing, it can be seen that $\mathrm{R}$ Square has a value of 0.517 or $51.7 \%$, this shows that Organizational Culture and Employee Engagement are able to explain changes in Employee Performance by $51.7 \%$. Meanwhile, the rest $(100 \%-51.7 \%=48.3 \%)$ is influenced by other factors, including leadership style, knowledge management, job satisfaction (Fuadi, 2019; Bassem, 2018, Kurniawan, 2018).

Table 5 Partial Influence

\begin{tabular}{|l|l|c|c|c|c|c|}
\hline Variable Y & \multicolumn{1}{|c|}{ Variable } & $\begin{array}{c}\text { Regression } \\
\text { Coefficient } \\
\text { (Beta) }\end{array}$ & $\begin{array}{c}\text { Correlation } \\
\text { coefficient } \\
(\mathrm{R})\end{array}$ & $\begin{array}{c}\mathrm{R} \\
\text { square }\end{array}$ & $\begin{array}{c}\text { Effective } \\
\text { Contribution }\end{array}$ & $\begin{array}{c}\text { Relative } \\
\text { Contribution }\end{array}$ \\
\hline $\begin{array}{l}\text { Employee } \\
\text { Performance }\end{array}$ & $\begin{array}{l}\text { Organizational } \\
\text { Culture(X1) }\end{array}$ & 0,400 & 0,671 & & $26,84 \%$ & $51,87 \%$ \\
\cline { 2 - 6 } & $\begin{array}{l}\text { Employee } \\
\text { Engagement } \\
(X 2)\end{array}$ & 0,375 & 0,664 & $51.7 \%$ & $24,90 \%$ & $48,12 \%$ \\
\hline
\end{tabular}

Source: Research Data Analyze, 2020 
Based on table 4.5, the results of data processing show that adding up the effective contribution will be the same as the $\mathrm{R}$ square value (51.7\%). Meanwhile, the partial influence on organizational culture has a value of $51.87 \%$ and Employee engagement has a value of $48.12 \%$. The results of this study indicate that organizational culture has a more dominant influence on employee performance at Telkom University.

The next step is to do a Hypothesis Test which consists of a simultaneous test and a partial test. Simultaneous hypothesis testing aims to determine whether there is a significant effect of Organizational Culture and Employee Engagement on Employee Performance simultaneously. The hypothesis proposed is as follows:

H0: $\beta=0$ : Organizational Culture and Employee Engagement do not have a significant effect on Employee Performance.

Ha: $\beta \neq 0$ : Organizational Culture and Employee Engagement have a significant effect on Employee Performance.

The criteria for the decision to accept / reject the hypothesis are as follows:

$\mathrm{F}_{\text {count }}>\mathrm{F}_{\text {table }}$ at the $95 \%$ confidence level $(\alpha=0.05)$, then $\mathrm{H} 0$ is rejected.

$\mathrm{F}_{\text {count }}<\mathrm{F}_{\text {table }}$ at the $95 \%$ confidence level $(\alpha=0.05)$, then $\mathrm{H} 0$ is accepted.

Ftable value with df1 $=2$; df $2=302$; and $\alpha=0.05$ which is 3.025 while the value of $\mathrm{F}_{\text {count }}$ based on the results of processing using SPSS version 26 software can be seen in the following ANOVA table:

Table 6 Simultaneous Hypothesis Test Results

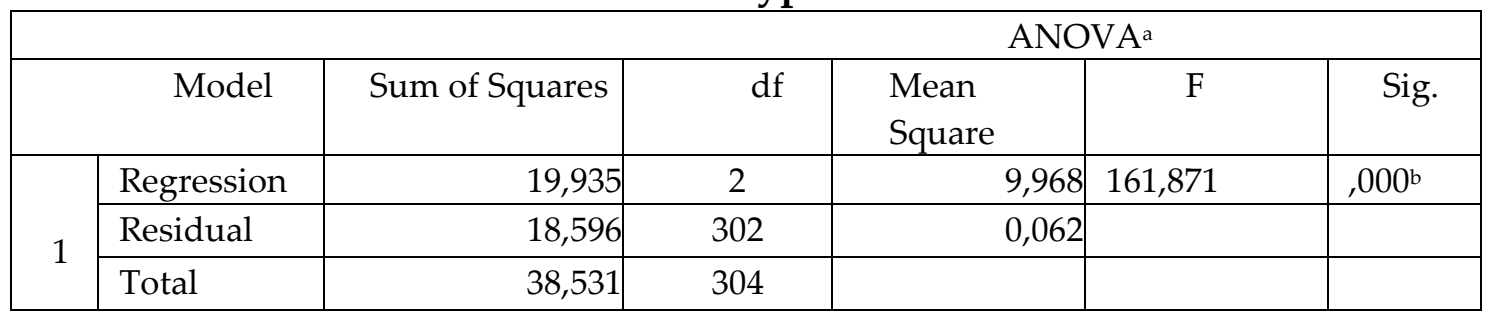

a. Dependent Variable: Employee Performances

b. Predictors: (Constant),Employee Engagement, Organizational Culture

Source: Research Data Analyze, 2020

The simultaneous test results shown in Table 4.6 show that the calculated value with $\mathrm{df} 1=2$ and $\mathrm{df} 2=302$ is 161,871 , testing through the comparison of the calculated value is $161,871>3,025$ then $\mathrm{H} 0$ is rejected. By comparing the significance value which has a value of $0.00<0.05$, H0 is rejected and Ha is accepted. Based on the test results, it can be concluded that together (simultaneously) there is a significant positive influence between Organizational Culture and Employee Engagement on Employee Performance.

Based on the results of testing the hypothesis simultaneously proves that Organizational Culture and Employee Engagement have a significant positive effect on the performance of Telkom University employees. This research is in line with several studies that have been conducted, such as research conducted by Hazriansyah (2017) which shows the results of research that organizational culture and employee engagement have a significant positive effect on employee 
performance. In addition, Fuadi (2019) also conducted research on organizational culture and Employee engagement and added job satisfaction variables to employee performance, and the results showed that Organizational Culture and Employee Engagement had a significant positive effect on employee performance. Another study conducted by Soni (2019) on organizational culture and employee engagement in manufacturing companies found that organizational culture and employee engagement had a significant positive effect on employee performance development. Based on the description above, it supports the results of previous studies which reveal that employees who have a high sense of engagement and a strong organizational culture can affect the performance of Telkom University employees.

Partial test or $t$ test is done by comparing the value of the statistical test with the null hypothesis, the criteria for the decision to accept or reject the hypothesis use 2 criteria, namely:

H0: There is no significant effect of Organizational Culture or Employee Engagement on Employee Performance.

Ha: There is a significant effect of Organizational Culture or Employee Engagement on Employee Performance.

The criteria for the decision to accept / reject the hypothesis are as follows:

$t_{\text {count }}>t_{\text {table }}$ at the $95 \%$ confidence level $(\alpha=0.05)$, then $\mathrm{H} 0$ is rejected.

$\mathrm{t}_{\text {count }}<\mathrm{t}_{\text {table }}$ at the $95 \%$ confidence level $(\alpha=0.05)$, then H0 is accepted.

The value of $t$ table with a significance level of $\alpha=0.05$ and $\mathrm{df}=302$ is 1.972 . The t-count value can be determined based on the t-test results shown in the following table:

Table 7 Partial Hypothesis Test Results

\begin{tabular}{|c|c|c|c|c|c|c|}
\hline & & \multicolumn{5}{|c|}{ Coefficients $^{a}$} \\
\hline \multirow{2}{*}{\multicolumn{2}{|c|}{ Model }} & \multicolumn{2}{|c|}{$\begin{array}{l}\text { Unstandardized } \\
\text { Coefficients }\end{array}$} & \multirow{2}{*}{$\begin{array}{c}\text { Standardized } \\
\text { Coefficients } \\
\text { Beta } \\
\end{array}$} & \multirow[t]{2}{*}{$\mathrm{t}$} & \multirow[t]{2}{*}{ Sig. } \\
\hline & & $\mathrm{B}$ & Std. Error & & & \\
\hline \multirow[t]{3}{*}{1} & (Constant) & 0,696 & 0,188 & & 3,707 &, 000 \\
\hline & Organizational culture & 0,440 & 0,064 & 0,400 & 6,901 &, 000 \\
\hline & Employee Engagement & 0,373 & 0,058 & 0,375 & 6,478 & ,000 \\
\hline
\end{tabular}

a. Dependent Variable: Employee Performances

Source: Research Data Analyze (2020)

Based on the results of the partial test shown in Table 6 above, it can be interpreted as follows:

a. Based on the calculations in table 6 above, it is obtained to count of 6.901, because it is greater than table $(6.901>1.972)$, then $\mathrm{HO}$ is rejected and $\mathrm{Ha}$ is accepted. The second criterion for Organizational Culture has a significance value of $0.000<0.05$, so that $\mathrm{H} 0$ is rejected and Ha is accepted. This means that organizational culture has a positive and significant influence on employee performance.

b. Based on the results of the calculations in table 6 above, the $t$ count is 6,478 , because it is greater than $\mathrm{t}$ table $(6,478>1,972)$, then $\mathrm{H} 0$ is rejected and $\mathrm{Ha}$ is 
accepted. The second criterion for Employee Engagement has a significance value of $0.000<0.05$, so that $\mathrm{H} 0$ is rejected and $\mathrm{Ha}$ is accepted. This means that Employee engagement has a positive and significant impact on employee performance.

\section{E. CONCLUSION}

The organizational culture at Telkom University is in the Strong category, Employee engagement is in the High category, then the employee performance at Telkom University is in the "above target" category. Partially, organizational culture has a positive $(51.87 \%)$ and significant effect on employee performance, this is supported by the calculation of $t$ count which is greater than $t$ table $(6.901>1.972)$, Likewise, Employee engagement has a positive (48.12\%) and significant effect on employee performance, this is supported by the calculation of $t$ count which is greater than $\mathrm{t}$ table $(6.478>1.972)$. Furthermore, simultaneously, organizational culture and employee engagement have a positive and significant influence on employee performance at Telkom University, with an influence of 51.7\%, where organizational culture has a more dominant influence in influencing employee performance.

\section{REFERENCES}

1. Aktar, A. (2017). Antecedents and Consequences of Employee Engagement: A Conceptual Study. IOSR Journal of Business and Management, 54-67.

2. de Bruin, G. P., \& Henn, C. M. (2013). Dimensionality of the 9-Item Utrecht Work Engagement Scale (UWES-9). Psychological Reports, 788-799.

3. Dessler, G. (2016). Human Resource Management. Florida: Pearson (15th Edition).

4. Fuadi, S. N. (2019). The Influence of Work Motivation, Organizational Culture, and Job Engagement on Employee Performance. International Conference on Technology, Education and Sciences.

5. Hazriansyah, M. (2017). The Influence Of Organizational Cculture With Employee Engagement on Performance (A Lesson from PT. Wika Bitumen Jakarta-Buton). International Journal of Scientific and Research Publications, 7(11), 502-510.

6. Indiyati, D. (2014). Pengaruh Budaya Organisasi dan Manajemen Pengetahuan Terhadap Keunggulan Bersaing. Sosiohumaniora, 193-200.

7. Indiyati, D. (2018). The Role of Organisational Culture, Intellectual Capital and Competitive Advantage in Supporting the Government Policies in Education, International Journal of Economic Policy in Emerging Economies, 11(1/2), 68-82

8. Indrawati. (2015). Metode Penelitian Manajemen dan Bisnis Konvergensi Teknologi Komunikasi dan Informasi. Bandung: PT Refika Aditama

9. Isa, M. F. (2016). The Influence of Organizational Culture on Employees' Performance: Evidence from Oman. Journal of Entrepreneurship and Business, 14(2), 1-12. 
10. Jane, P. (2018). Employee engagement, positive organizational culture and individual adaptability. On the Horizon, 206-214.

11. Jiony, M. M. (2015). Understanding the Effect of Organizational Culture and Employee Engagement on Organizational Performance Using Organizational Communicationas Mediator: A Conceptual Framework. American Journal of Economics, 5(2), 128-134.

12. Krog, A. (2014). The Relationship Between Organizational Cultureand Work Engagement: A Multilevel Investigation.

13. Kurniawan, F. (2018). Pengaruh Knowledge Management dan Lingkungan Kerja Terhadap Kinerja Karyawan Dengan Kepuasan Kerja Sebagai Variabel Intervening (Studi Pada Tenaga Kependidikan Universitas X Yogyakarta).

14. Kuswati, Y. (2020). The Influence of Organizational Culture on Employee Performance. Budapest International Research and Critics Institute (BIRCI-Journal) : Humanities, 3(1).

15. Macey, W. (2009). The "Feel and Look" of Employee Engagement. In Employee Engagement: Tools for Analysis, Practice, and Competitive Advantage (pp. 19-42).

16. Mariam, R. (2009). Pengaruh Gaya Kepemimpinan dan Budaya Organisasi Terhadap Kinerja Karyawan Melalui Kepuasan Karyawan Sebagai Variabel Intervening (Studi Pada PT Asuransi Jasa Indonesia).

17. Mathis, R. (2016). Human Resource Management.

18. Molraudee, S. (2016). Performance management to enhance employee engagement for corporate sustainability. Asia-Pacific Journal of Business Administration, 84-102.

19. Nabil, I. (2019, January). Employee engagement and job performance in Lebanon: the mediating role of creativity. International Journal of Productivity and Performance Management, 68(3), 506-523. doi:10.1108/IJPPM-02-2018-0052

20. Nazneen, A. (2018). Impact of Employee Engagement and Organizational Culture in High Performing Accredited University of Saudi Arabia. International Journal of Accounting and Financial Reporting, 8(4).

21. Owais, N. (2017). Enhancing organizational commitment and employee performance through employee engagement: An empirical check. South Asian Journal of Business Studies, 98-114.

22. Prayudha, H. W. (2018). Pengaruh Employee Engagement dan Budaya Organisasi Terhadap Kinerja Karyawan Melalui Kepuasan Kerja Sebagai Variabel Intervening di Universitas Islam Indonesia.

23. Robbins, S. P. (2018). Management (Vol. 14th). Pearson Education Limited.

24. Robbins, S., \& Judge, T. (2017). Organizational Behavior. Pearson 17th Edition.

25. Saunders, M. (2019). Research Methods for Business Students" Chapter 4: Understanding research philosophy and approaches to theory development.

26. Schaufeli, W. B., \& Bakker, A. B. (2006). The Measurement of Work Engagement With a Short Questionnaire: A Cross-National Study. Educational and Psychological Measurement, 701-716. 
27. Sekaran, U., \& Bougie, R. (2016). Research methods for business: A skill building approach. John Wiley \& Sons.

28. Soni, S. (2019). Impact of Organizational Culture on EmployeeEngagement and Effectiveness in Indian Manufacturing Company. IITM Journal of Management and IT.

29. Suharno, P. (2017). The effect of work environment, leadership style, and organizational culture towards job satisfaction and its implication towards employee performance in Parador Hotels and Resorts, Indonesia. International Journal of Law and Management, 1337-1358.

30. Suharno, P. (2017). The influence of organizational culture on the performance of employees at University of Mercu Buana. International Journal of Law and Management, 950-963.

31. Taufiqurokhman. (2009). Mengenal Manajemen Sumber Daya Manusia. Jakarta: Fakultas Ilmu Sosial dan Ilmu Politik Universitas Prof. Dr. Moestopo Beragama.

32. Wong, M. A. (2014). Entrepreneurial Culture: Developing a Theoretical Construct and its Measurement. 2138.

33. Zoltán, K. (2018). Relationships between employee commitment and organizational cultures: a theoretical framework. International Journal of Organizational Analysis, 398-414.

34. Zulganef. (2008). Metode Penelitian Sosial E Bisnis. Yogyakarta: Graha Ilmu. 